\title{
Book Review: The Arab Awakening: Islam and the New Middle East, Tariq Ramadan, 2012, London: Allen Lane, pages: 273.
}

\author{
WAN FARIZA ALYATI WAN ZAKARIA ${ }^{1}$
}

This book discusses the current situations in the Middle East and how the changes affected the people and the future of the Muslim world. Ramadan stated that the book does not claim ". . . to reveal secrets, to unveil what may be strategic goals, and even less to predict the future" for to do so would mean madness, which he regards as a combination of presumption and vanity (p: ix). What he attempts to do is to reexamine the facts, study the realities and to suggest some lessons, or to use Ibn Khaldun's terminology - cibra - not only for the Arab world and the Muslim majority countries but also for keen observers of the phenomenal developments. Ramadan poses three important questions in analyzing the issues at hand: 1, what really happened in Tunisia and Egypt? 2, what is happening in the broader region that makes up the Middle East and North Africa (MENA)? And finally, why now? He stresses that to answer the questions, we must study the recent history and its actors, as well as political, geopolitical and economic contexts of the region. He also argues that the terms that are used to describe the phenomena - 'Arab Spring, revolutions and upheavals' - should also be scrutinized, as the components of these movements are less known let alone the outcome. Throughout this study, he attempts to demonstrate that the protest movements should not be thought as being designed and manipulated by the West (the US and Europe) as such claim would mean that human beings are unable "... to assert themselves as the subject of their own history" but rather the ability of the peoples of the region to act upon their own destiny by overthrowing the dictators without weapons (p: xi). This historic moment has opened up a few fundamental questions regarding the nature of the state, the role of religion, the basic principle of equality etcetera which bound to fall under the bipolar debate between 'secularists' and 'Islamists'. Clearly, he states that the book attempts to demonstrate that such polarizing debate cannot be reduced to a confrontation between both approaches.

Ramadan also emphasizes the role of the Muslim intellectuals and politicians in this time of radical and comprehensive renewal process in identifying the key issues, defining and prioritizing the ways and means for social and political reform as well as fostering the emergence of a true civil society in the region. He stresses that Arab and Muslim majority societies should stop "... blaming the West for the colonialism and imperialism of the past, or for today's attempts at manipulation and control" (p: xii) but to ". . reconcile themselves with the course of history ..." (ibid.) and ". . . be wary of attempts at manipulation, and be determined to carry out essential reforms ..." (ibid.).

The book consists of four chapters excluding the introduction and conclusion. The first chapter entitled Made-to-order uprisings?; the second chapter entitled Cautious Optimism, chapter three, Islam, Islamism, Secularization and the final chapter, The Islamic Reference. In the first chapter, Ramadan has briefly outlined the situations in the Middle East and North Africa since the first event that sparked the whole process - the suicide of Mohamed Bouazizi in Tunisia. He argues that the claim of Western manipulation on the issue of change of government through funding the opponents of the Arab governments cannot be underestimated but at the same time cautious optimism towards a major shift in

${ }^{1}$ Wan Fariza Alyati Wan Zakaria, Ph.D., Senior Lecturer at the Department of Theology and Philosophy, Universiti Kebangsaan Malaysia, 43600 Bangi, Selangor, Malaysia. Email: aufaa@ukm.my. 
the region. He also claimed that the US administration and certain European countries had funded the training programs of a core group of cyber activists and helped develop organized networks of bloggers in the Middle East and North Africa. But the most striking point he asked in this chapter is on the capacity of the people to produce new models of democracy based on their own referential framework and values after the uprisings or whether they fall into the trap of a conciliatory synthesis with the West has become the central and complex issue that should not be eluded.

The second chapter consists of discussion on the role of Islam as a reference in the current process of the Arab uprisings. There are 6 subtitles under this chapter: Understanding: Manipulation Or Liberation, Unequal Treatment, The Role Of The Media, The Death of Osama Bin Laden, On the West, Politics And The Economy and finally, What Lies Ahead For Muslim-Majority Societies? Overall, the discussion put forward by Ramadan in this chapter is regarding challenges and obstacles within the Middle East and North Africa: the lack of clear leadership in the current mass movements, the limited selfawareness combined with dualistic vision of political realities, the neglection of economic and global dynamics and finally the sectarian tension between the Sunnis and the Shiites. In concluding the chapter, he says enthusiastically: "Whatever the schemes and the manipulation of the Great Powers, the future of Arab awakening will depend on the capacity of each society to take its fate into its own hands, to develop new approaches and to open new perspectives...Now the time has come for the young people who carried forward the Arab awakening to shape and determine - beyond their mastery of technology and technique - a vision, a project, an alternative" (p:71). These statements underline his point in the first chapter on the dire need for new approaches and models, new project and alternative for the future of the Arab people in the region.

In the third chapter entitled Islam, Islamism, Secularization, Ramadan analyses the place of Islam in society by focusing on two main themes: the compatibility of Islam with democratic pluralism and religious diversity and, the role of Islamist parties in the societies after liberation from dictatorship. He firstly gives an overview on the diverse interpretations of Islam that resulted in layers or levels of diversity and also the influence of cultures that resulted in plurality of cultures. He then continues with a brief historical account on the Islamist movements back to the late nineteenth century until today and stresses that "Islamism began as a legalist, non-violent movement based on a strategy or reform from the bottom up...failure and repression brought about changes"(p:79). The Arab awakening, he argues, has shown how far such movements are from young people's concern and aspirations. He then turns the discussion on secularization and how the meaning has a different connotation from the Western secularization. Secularization in Muslim majority and Arab societies according to Ramadan, has been identified with repression, colonialism and the assault on Islam. This was done - in Turkey, Tunisia and most Arab countries - by placing religion under state control. Both the Islamists and the secularists, he asserts, share the same attitude - shunning self-criticism, and confining themselves to an empty, outdated and counterproductive paradigm. He moves forward by proposing Turkey as the model for reconciliation between secularists and Islamists as an alternative project for democracy. In the last point of the chapter, he is convinced that the Turkish model should be seen as a means rather than an end to path the way for the future of Arab democracies.

The final chapter, The Islamic Reference, discusses the challenge for the Arab individual in particular and Muslims in general to become the subjects of their own history through deep and critical reconciliation with the core and the essence of their own tradition. He then discusses political Islam in the present context and whether it will end or continue to survive in different tunes. He also discusses the debate on the establishment of 
civil state and Islamic state that had become the landmark of the early twentieth century. He notes: "these reflections on the civil character of the state (dawla madaniyya) and on the role of religious and cultural references (as ethical framework or as a reminder of the ultimate goals that should inform action) must lead to the formulation of clear positions"(pp:123-4). On the role of the economic aspects of the new social and political configuration, Ramadan also questions the readiness of contemporary Muslim thought to offer ethical and economic alternatives. This is because the current economic order is far from the spirit of Islam and will continuously undermine the Arabs and Muslims in the long run. He also urges the people to reclaim the self and reconcile the meaning of their tradition. Conclusively, he states that contemporary Muslims must involve in this critical undertaking and to chart a new vision for themselves and for the rest of humanity.

Ramadan's conclusions can be summarized into three points: firstly, there are real issues that need to be addressed to create genuine upheaval in the Arab society that encompass education, social, political, new economic prospects, cultural and artistic areas. Secondly, that Arab society should be better acquainted with their own history, tradition and values. And thirdly, the need for self-criticism and inward reflections on their strengths and weaknesses, to build, to contribute, to define priorities and to determine goals. Only then they can hold the reins of their destiny.

Generally, the book can be regarded as one of the great works by Tariq Ramadan. He has consistently put forward his reformist ideas by maintaining the appreciation for the past, understanding the present and charting possibilities of the future for the Muslim societies. This work can only be done by the enlightened soul combined with activist spirit. 